\title{
Effects of the Light Irradiance on the Growth and Lipids Content of Amphidinium Carterae (Dinophyceae) for Biofuels Production
}

\section{Armando Mendoza-Flores}

Centro de Investigación Científica y de Educación Superior de Ensenada (CICESE)

Clara Elizabeth Galindo-Sánchez

Centro de Investigación Científica y de Educación Superior de Ensenada (CICESE)

M. del Pilar Sánchez-Saavedra ( $\nabla$ psanchez@cicese.mx )

Centro de Investigacion Cientifica y de Educacion Superior de Ensenada https://orcid.org/0000-00019324-9224

\section{Research Article}

Keywords: Amphidinium carterae, growth rate, biomass production, lipids, photosynthesis, proximal composition

Posted Date: January 14th, 2022

DOI: https://doi.org/10.21203/rs.3.rs-1255335/v1

License: (c) (i) This work is licensed under a Creative Commons Attribution 4.0 International License. Read Full License

Version of Record: A version of this preprint was published at BioEnergy Research on April 22nd, 2022. See the published version at https://doi.org/10.1007/s12155-022-10455-9. 


\section{Abstract}

The irradiance level used to the microalgae cultures can modify the growth and proximate composition, however, this response is specie specific. The dinoflagellate group had the potential to be used as a source to biofuel production. In this study was evaluated the effect of five irradiance levels $(50,100,150$, 200 , and $250 \mu \mathrm{mol}$ photon $\mathrm{m}^{-2} \mathrm{~s}^{-1}$ ) on the growth rate, proximal composition, pigment content, and photosynthesis of Amphidinium carterae. The highest cell concentration was for the cultures at $150 \mu \mathrm{mol}$ photon $\mathrm{m}^{-2} \mathrm{~s}^{-1}\left(130 \times 10^{3}\right.$ cells $\left.\mathrm{mL}^{-1}\right)$, and the lowest values for $50 \mu \mathrm{mol}$ photon $\mathrm{m}^{-2} \mathrm{~s}^{-1}\left(49 \times 10^{3} \mathrm{cells} \mathrm{mL}^{-}\right.$ $\left.{ }^{1}\right)$. The cultures maintained under the low irradiance $\left(50 \mu \mathrm{mol}\right.$ photon $\left.\mathrm{m}^{-2} \mathrm{~s}^{-1}\right)$ had the highest values of total dry weight (TDW) (13418 pg cell $\left.{ }^{-1}\right)$, organic dry weight (ODW) (3836 pg cell $\left.{ }^{-1}\right)$, and inorganic dry weight (IDW) (9582 $\left.\mathrm{pg} \mathrm{cell}^{-1}\right)$. The protein content as the general trend increases significantly concerning the irradiance level, with the higher values $\left(87.47 \mathrm{pg} \mathrm{cell}^{-1}\right)$ at high irradiance $\left(250 \mu \mathrm{mol}\right.$ photon $\left.\mathrm{m}^{-2} \mathrm{~s}^{-1}\right)$. Carbohydrate content was different by the effect of irradiance, with the higher values $\left(32.85 \mathrm{pg} \mathrm{cell}^{-1}\right)$ at the low irradiance used $\left(50 \mu \mathrm{mol}\right.$ photon $\left.\mathrm{m}^{-2} \mathrm{~s}^{-1}\right)$. Lipid content was modified by the effect of irradiance, with the highest values ( $\left.534.74 \mathrm{pg} \mathrm{cell}^{-1}\right)$ at the low irradiance used $\left(50 \mu \mathrm{mol}\right.$ photon $\left.\mathrm{m}^{-2} \mathrm{~s}^{-1}\right)$. As a general trend, the high irradiances increased the photosynthesis curves. These findings demonstrate that the strain of $A$. carterae used in this work can grow in high irradiances (100 to $250 \mu \mathrm{mol}$ photon $\mathrm{m}^{-2} \mathrm{~s}^{-1}$ ) and increase significantly the lipid content on low irradiance used $\left(50 \mu \mathrm{mol}\right.$ photon $\left.\mathrm{m}^{-2} \mathrm{~s}^{-1}\right)$.

\section{Introduction}

Rapidly exhausting fossil fuels and combined with the increasing demand for energy led to search alternative energy sources [1]. Microalgae are a promising source for proteins, lipids and carbohydrates for the food/feed and biofuel industry. For alternative biofuel production microalgae represents ventages due low environmental impact, carbon sequestration, high lipid content and rapid growth; in comparison with soya and palm oil, microalgae can be grown in a more efficient and sustainable way [2]. However, to obtain a good economic-production benefit, microalgal cultivation requires good light source, effective mass transfer, minimal or no contamination, low infrastructure, and land cost [1].

Microalgae are photosynthetic organism source of many high-value-added metabolites; besides lipids which are used for biofuels productions, proteins, carbohydrates, carotenoids, fatty acids and pigments, can be used as feedstock for applications in cosmetics, pharmaceutical, animal and human nutrition [3]. Current researches are focused on developing cultivation strategies for production of lipids and other value-added products in laboratory-scale biorefineries [4].

Dinoflagellates are associated with the production of many marine toxins, which are of interest for their commercial impact, potential medical, pharmacological research, and other applications [5]. Also, marine dinoflagellates are a source of numerous bioactive compounds, besides toxins, with commercial interest [6]. Peridinin is a carotenoid present in the dinoflagellates and has potential use in medicine as a therapeutic agent against different diseases [7]. The dinoflagellate group can accumulate large amounts 
of lipids, and they can be used as an alternative source to chemical products used as biofuels [8], pharmaceutical, and nutritional applications. The EPA (eicosapentaenoic acid), ARA (arachidonic acid) and DHA (docosahexaenoic acid) are some of the most important fatty acids in nutrition [9].

The Amphidinium genus is the most abundant and diverse dwelling benthic dinoflagellates species worldwide [10]. This group includes organisms with diverse habitats as marine, freshwater species, autotrophic, mixotrophic, and heterotrophic nutrition, pelagic and benthic forms [11]; they produce toxins and bioactive compounds with harmful effects [12]. The main bioactive compounds produced by Amphidinium cells are the amphidinols (polyketides). The amphidinols are compounds with antifungal and hemolytic activities $[12,13]$, and in less frequent cases, cytotoxic activity was used for anticancer activity [14]. However, Amphidinium also has other bioactive compounds with commercial interest, like polyunsaturated fatty acids and carotenoids [15]. The species Amphidinium carterae is the most used of the genus in studies for biomass production with photobioreactors for production of carotenoids, fatty acids, and amphidinols [15-17].

One of the significant factors affecting algae growth is light [18]. As for all photosynthetic organisms, sunlight supports their metabolism, and its efficient conversion into biomass significantly influences productivity [8]. The knowledge of photosynthesis efficiency of the microalgae strain is a critical parameter in the mass microalgae cultures $[8,19]$. In closed growing systems the light conditions can be changed, and this can be used to increase the productivity of microalgae cultivation [20].

Light is the driving force of photosynthesis in algal productivity. The photosynthesis versus irradiance curve shows three regions: a) an initial light-limited area at low light irradiance where photosynthetic rates increase with increasing irradiance. b) light-saturated region where photosynthetic rates are independent of irradiance. c) area of photoinhibition, where photosynthesis decreases when irradiance increases to the limit of each strain [21]. An increase in irradiance stimulates growth; however, if present in excess, the growth is not stimulated, having an inhibitory effect causing a reduction in duplication rate, and may lead to the formation of harmful reactive oxygen species (ROS) and oxidative stress [22].

In this work, was evaluated the effect of five irradiances levels $(50,100,150,200$, and $250 \mu \mathrm{mol}$ photon $\mathrm{m}^{-2} \mathrm{~s}^{-1}$ ) on the growth rate, proximal composition, pigment content, and photosynthesis of Amphidinium carterae.

\section{Materials And Methods}

\section{Culture conditions}

Amphidinium carterae was isolated from Bahía Todos Santos, Ensenada, Mexico in 2015, from a bloom. Batch cultures were maintained in $125 \mathrm{~mL}$ flasks with $110 \mathrm{~mL}$ of "f" media [23] in seawater at $20 \pm 1^{\circ} \mathrm{C}$, with 12:12 h light: dark photoperiod. The $\mathrm{pH}$ was measured daily at initial values of 7.8 , which increased throughout the culture to reach values of 8.2 . 
Triplicate batch cultures were grown with the conditions described above in five different irradiances: 50, $100,150,200$, and $250 \mu$ mol photons $\mathrm{m}^{-2} \mathrm{~s}^{-1}$; the light was provided by $40 \mathrm{~W}$ white fluorescent lamps (Philips F40 T12/DX). The five irradiances were obtained, adjusting the distance of the culture to the lamp and measured at the center of the surface of the flask with a $4 \pi$ QSL-100 quantum radiometer (Biospherical Instruments, USA).

\section{Growth rate}

Every day $1 \mathrm{~mL}$ of the cultures was fixed with Lugol iodine, cell density was measured by direct count using a hemocytometer with a microscope Olympus CX31. The exponential growth rates were calculated according to Guillard [24].

\section{Pigments and photosynthesis}

For pigments analyses, $5 \mathrm{~mL}$ of each culture at day 8 of growth was filtered through GF/F glass microfiber filters and frozen immediately at $-20^{\circ} \mathrm{C}$. Pigments were extracted with $3 \mathrm{~mL}$ of acetone $90 \%$, and the concentrations were determined by Jeffrey and Humprey [25].

Samples for photosynthesis $(15 \mathrm{~mL})$ were collected on day 8 of the culture. Photosynthesis was analyzed using rapid light curves on a pulse amplitude modulation (PAM) fluorometer (Walz, junior PAM). Photosynthetic efficiency $(a)$, irradiance of saturation $\left(I_{k}\right)$, the relative electron transport rate $(r E T R)$ and the maximum quantum yield of photosystem II (Fv/Fm) values were obtained for each treatment [26].

\section{Dry weight and proximate composition}

To measure total dry weight (TDW), triplicate 13-mL samples at day 8 of growth were passed through washed and preweighted $47 \mathrm{~mm}$ Whatman GF/C glass fiber filters (1- $\mu \mathrm{m}$ pore), rinsed with $25-\mathrm{mL}$ ammonium formate (3\%) to remove salt residues, and dried at $60^{\circ} \mathrm{C}$ to a constant weight. To measure the ash content (IDW), the filters with cell biomass were incinerated at $450^{\circ} \mathrm{C}$ for $4 \mathrm{~h}$. The organic dry weight (ODW) was calculated as the difference between the total dry weight and ash content per Sorokin [27].

To measure the proximate composition, $10 \mathrm{~mL}$ samples were passed through washed $25 \mathrm{~mm}$ Whatman $\mathrm{GF} / \mathrm{C}$ glass microfiber filters and stored at $-20^{\circ} \mathrm{C}$ for further analysis. Water-soluble proteins were extracted with $0.1 \mathrm{~N} \mathrm{NaOH}$ at pH 12 and $80^{\circ} \mathrm{C}$ for 20 min as described by Safi et al. [28], and the content was quantified by Lowry et al. [29]. A calibration curve was generated using bovine serum albumin (98\%) as the standard. Carbohydrates were extracted per Whyte [30] and quantified by the phenol-sulfuric method [31]. Lipids were extracted per Bligh and Dyer [32], and quantified as described by Pande et al. [33]. A calibration curve for lipids was generated using tripalmitin (99\%) as standard.

\section{Statistical analysis}


All data were tested for homoscedasticity and normality. Differences in growth rate, TDW, IDW, ODW, proximate composition (proteins, carbohydrates, and lipids), chlorophyll a, carotenoid and photosynthetic parameters ( $a, E T R r, l k$, and Fv/Fm) were analyzed for each variable in a triplicate set by one-way analysis of variance (ANOVA). Differences in cell concentration were analyzed by covariance analysis (ANCOVA). When significant differences were obtained, Tukey a posteriori test was performed. The data analyses was performed using the software Statistica 7.0, and the significance level was set to $p<0.05$ in all cases.

\section{Results}

\section{Growth rate}

The cell densities of Amphidinium carterae maintained under the five irradiances differed significantly over time ( $p<0.05$, Fig. 1$)$, increasing rapidly depending on the irradiance used. The highest cell concentration ( $130^{\prime} 10^{3} \mathrm{cell} \mathrm{mL}^{-1}$ ) was measured for the cultures at $150 \mu \mathrm{mol}$ photon $\mathrm{m}^{-2} \mathrm{~s}^{-1}$, and the lowest values for $50 \mu \mathrm{mol}$ photon $\mathrm{m}^{-2} \mathrm{~s}^{-1}\left(49 \times 10^{3}\right.$ cells $\left.\mathrm{mL}^{-1}\right)$ (Fig. 1).

Growth rates were significantly different by the effect of the irradiance $(p<0.05$, Fig. 2$)$. The highest growth rate values ( 0.63 to 0.67 div day $^{-1}$ ) were obtained at the irradiances of 150 to $250 \mu$ mol photon m $2 \mathrm{~s}^{-1}$ and the lowest $\left(0.43\right.$ div day $\left.^{-1}\right)$ at $50 \mu \mathrm{mol}$ photon $\mathrm{m}^{-2} \mathrm{~s}^{-1}$.

\section{Dry weight and proximal composition}

The TWD $(p<0.05)$, ODW $(p<0.05)$, and IDW $(p<0.05)$ values differed significantly by the effect of irradiance (Fig. 3). The cultures at low irradiance $\left(50 \mu \mathrm{mol}\right.$ photon $\left.\mathrm{m}^{-2} \mathrm{~s}^{-1}\right)$ had the highest values of TDW (13418 $\left.\mathrm{pg} \mathrm{cell}^{-1}\right)$, ODW (3836 pg cell $\left.{ }^{-1}\right)$, and IDW (9582 $\left.\mathrm{pg} \mathrm{cell}^{-1}\right)$. The TDW, ODW, and IDW values obtained for the irradiances from 100 to $250 \mu \mathrm{mol}$ photon $\mathrm{m}^{-2} \mathrm{~s}^{-1}$ were unchanged (Fig. 3).

The proximate composition differed significantly $(p<0.05)$ depending on the irradiance level (Fig. 4). The protein content as the general trend increases with regards the irradiance level $(p<0.05)$, with the highest values $\left(87.47 \mathrm{pg} \mathrm{cell}^{-1}\right)$ at high irradiance $\left(250 \mu \mathrm{mol}\right.$ photon $\left.\mathrm{m}^{-2} \mathrm{~s}^{-1}\right)$, and the lowest values $(62.04 \mathrm{pg}$ cell $\left.{ }^{1}\right)$ at low irradiance $\left(50 \mu \mathrm{mol}\right.$ photon $\left.\mathrm{m}^{-2} \mathrm{~s}^{-1}\right)$. Carbohydrate content was significantly different by the effect of irradiance $(p<0.05)$, with the highest values $\left(32.85 \mathrm{pg} \mathrm{cell}^{-1}\right)$ at the low irradiance used $(50 \mu \mathrm{mol}$ photon $\left.\mathrm{m}^{-2} \mathrm{~s}^{-1}\right)$. The lipid content was modified significantly by the effect of irradiance $(p<0.05)$, with the highest values $\left(534.74 \mathrm{pg} \mathrm{cell}^{-1}\right)$ at the low irradiance $\left(50 \mu \mathrm{mol}\right.$ photon $\left.\mathrm{m}^{-2} \mathrm{~s}^{-1}\right)$.

\section{Pigments and photosynthesis}

The chlorophyll a content was significantly affected by the irradiance level $(p<0.05)$, the content of chlorophyll a had an inverse trend concerning the irradiance level (Fig. 5). The chlorophyll c content $(p>0.05)$ and carotenoid content $(p>0.05)$ were not significantly modified by the effect of irradiance (Fig. $5)$. 
The Fv/Fm values were significantly different by the effect of irradiance $(p<0.05$, Fig. 6$)$, the lower value (0.21) was for the low irradiance $\left(50 \mu \mathrm{mol}\right.$ photon $\left.\mathrm{m}^{-2} \mathrm{~s}^{-1}\right)$. The $\mathrm{Fv} / \mathrm{Fm}$ were maintained with similar values for the other irradiance levels used (100 to $250 \mu \mathrm{mol}$ photon $\left.\mathrm{m}^{-2} \mathrm{~s}^{-1}\right)$.

The photosynthesis curves were significantly affected by the irradiance level of the cultures $(p<0.05$, Fig. 7). As a general trend was found a direct relationship between the irradiance level and the photosynthesis curves magnitude.

The photosynthetic parameters also differed among irradiance levels $(p<0.05)$. The photosynthetic efficiency (a) ( $p<0.05)$, ETRm $(p<0.005)$, and Ik $(p<0.05)$ were affected by the irradiance level used (Table 1).

\section{Discussion}

This study describes the effects of five different irradiances on the growth and lipid content of Amphidinium carterae maintained in culture conditions. This work obtained changes in the growth rate of A. carterae by the effect of irradiance, with the highest values from 150 to $200 \mu \mathrm{mol}$ photon $\mathrm{m}^{-2} \mathrm{~s}^{-1}$, and the lowest values at $50 \mu \mathrm{mol}$ photon $\mathrm{m}^{-2} \mathrm{~s}^{-1}$.

When A. carterae (Woods Hole Amphi 1) was maintained at $15^{\circ} \mathrm{C}$ under different irradiances ( 2 to 150 $\mu$ mol photon $\left.\mathrm{m}^{-2} \mathrm{~s}^{-1}\right)$, found that at low irradiances grow well $\left(15 \mu \mathrm{mol}\right.$ photon $\left.\mathrm{m}^{-2} \mathrm{~s}^{-1}\right)$ and has photoinhibition at irradiances of $150 \mu \mathrm{mol}$ photon $\mathrm{m}^{-2} \mathrm{~s}^{-1}$ [34]. When A. carterae (Amphi 1) was grown in " $\mathrm{f} / 2$ " media at $19{ }^{\circ} \mathrm{C}$, and from 10 to $50 \mu \mathrm{mol}$ photon $\mathrm{m}^{-2} \mathrm{~s}^{-1}$ the growth rate was linearly proportional to irradiance, and the maximum growth was at $80 \mu \mathrm{mol}$ photon $\mathrm{m}^{-2} \mathrm{~s}^{-1}$ in batch cultures [35]. The growth of A. carterae (Amphi 1) was higher under continuous light (24:0), with regards to the values obtained at $12: 12 \mathrm{in} \mathrm{"f} / 2$ " media, shaking at $100 \mathrm{rpm}$, at $20^{\circ} \mathrm{C}$ with $80 \mu \mathrm{mol}$ photon $\mathrm{m}^{-2} \mathrm{~s}^{-1}$ [36].

The growth rate obtained in this study for $A$. carterae at high irradiances (100 to $250 \mu$ mol photon $\mathrm{m}^{-2}$ $\mathrm{s}^{-1}$ ) was higher ( 0.59 to 0.67 divisions day $^{-1}$ ), with regards to the growth rate values ( 0.15 to 0.55 divisions day $^{-1}$ ) reported to $A$. carterae isolated from macroalgae and grow in low irradiances (35 to 70 $\mu \mathrm{mol}$ photon $\mathrm{m}^{-2} \mathrm{~s}^{-1}$ ) [37]. Also, the growth rates obtained in this study were higher than the values measured for the cultures of $A$. cartaerae (CCMP1314) maintained at $20^{\circ} \mathrm{C}$ with $100 \mu$ mol photon $\mathrm{m}^{-2}$ $\mathrm{s}^{-1}$ supply $14: 10$ hrs light: dark under P-repleted $\left(0.52\right.$ divisions day $\left.{ }^{-1}\right)$ and P-deprived ( 0.27 divisions day $^{-1}$ ) [38]. For $A$. carterae cultures maintained with irradiances of 50 to $750 \mu \mathrm{mol}$ photon $\mathrm{m}^{-2} \mathrm{~s}^{-1}$, the higher growth rate was at $300 \mu \mathrm{mol}$ photon $\mathrm{m}^{-2} \mathrm{~s}^{-1}$ during the first 5 days of culture [39]. The growth rate values obtained for $A$. carterae in this work were different from those mentioned by other authors, possibly for the differences from the origin of the strain and the different culture conditions used. 
In this work, it was obtained as a general trend, that growth rate and cell concentration increased proportionally to irradiance level with higher values among 150 to $250 \mu \mathrm{mol}$ photon $\mathrm{m}^{-2} \mathrm{~s}^{-1}$. Over this limit of irradiance level, the rise of light intensity did not increase the growth rates, suggesting that saturation photosynthesis was achieved. This pattern has also been described in Scenedesmus obliquus cultures, when growing at different irradiances 200 to $1000 \mu \mathrm{mol}$ photon $\mathrm{m}^{-2} \mathrm{~s}^{-1}$, and found the higher growth at $150 \mu \mathrm{mol}$ photon $\mathrm{m}^{-2} \mathrm{~s}^{-1}$ [22]. Photoacclimation probably supports the tolerance to high irradiances and tolerates a wide range of light intensities for different phytoplankton species. In the benthic dinoflagellate Gambierdiscus spp. photoacclimation permits that grow at high irradiances [40]. Photoacclimation of $A$. carterae in batch cultures allowed at high irradiances ( $300 \mu$ mol photon $\left.\mathrm{m}^{-2} \mathrm{~s}^{-1}\right)$ the maximum growth rate of 0.65 divisions day ${ }^{-1}$ [16], which those growth rates are similar to those obtained in this study.

Light is an important energy source and an essential factor in photosynthesis [19]. If the light intensity is too low in phytoplankton cultures, logarithmic growth will not prevail [41]. The results obtained with $A$. carterae showed that at an irradiance of $50 \mu \mathrm{mol}$ photon $\mathrm{m}^{-2} \mathrm{~s}^{-1}$ grows lower than the different irradiances used; thus, the low irradiance level used was insufficient to promote a high growth rate. $A$. carterae cultured in 12:12 LED-lighted raceway photobioreactor had high growth at irradiances between 100 to $289 \mu \mathrm{mol}$ photon $\mathrm{m}^{-2} \mathrm{~s}^{-1}$, reaching the stationary growth phase at nine days of culture [16]. The results obtained with $A$. carterae showed that the logarithmic growth phase was achieved at least for eight days of culture and that irradiances below $100 \mu \mathrm{mol}$ photon $\mathrm{m}^{-2} \mathrm{~s}^{-1}$ are limiting for cell growth.

In cultures of Scedenesdum obliquus, when the cells are stressed, they decrease or stop reproduction and increase cellular weight [22]. This pattern was observed on the cultures of $A$. carterae maintained at an irradiance of $50 \mu \mathrm{mol}$ photon $\mathrm{m}^{-2} \mathrm{~s}^{-1}$; in this irradiance, the cell decreases their growth, and the cell components used to reproduce are storage and consequently increase cell weight; under unfavorable environmental or stress conditions, many algae increase and accumulate neutral lipids which serve primarily as a storage form of carbon and energy [42]. In this work, the TDW, ODW, and IDW were not modified by irradiance at values between 100 to $250 \mu \mathrm{mol}$ photon $\mathrm{m}^{-2} \mathrm{~s}^{-1}$; this trend was due to the cells maintaining a similar growth under these irradiance values.

The lipid content of $A$. carterae had significant modifications by the effect of light irradiances and showed the highest values (534 $\mathrm{pg} \mathrm{cell}^{-1}$ ) with the low irradiance. Previous reports mentioned that $A$. carterae could produce lipids content from $7.2 \%$ and $9.2 \%$ of dry weight [43]; in this study, lipids represent between $3.6-14 \%$ of dry weight ( 52 to $534 \mathrm{pg} \mathrm{cell}^{-1}$ ), the lipid content of some marine diatoms can change from $22.7 \%$ when grows under normal conditions to $44.6 \%$ when was maintained under stress conditions [42]. The lipid content of $A$. carterae under the five irradiances in this work was higher than the values obtained to other studies (20 to $30 \mathrm{pg} \mathrm{cell}^{-1}$ ) with the same specie but obtained from Woods Hole (Amphi 1) culture with " $\mathrm{f} / 2$ " media, $20^{\circ} \mathrm{C}$ and $50 \mu \mathrm{mol}$ photon $\mathrm{m}^{-2} \mathrm{~s}^{-1}$ [35]. Microalgae like Scenedesmus obliquus and Dunaliella salina present the highest lipids content in high irradiances [22, 44]. However, Nanochloropsis sp. produce a high lipid content at low irradiances [41]. The effect of the light irradiance 
on the proximate composition is species-specific, and their modifications are related to each strain characteristic. In this work, $A$. carterae decreases the growth rate at the lowest irradiance, consequently increasing the storage products as lipids.

The neutral lipids in the mainly form of tryacylglycerols can be converted to fatty acid methyl esters and used as biofuel [45]. Lipids serves in two ways; as energy reserves and structural components of the membranes of the cell [46], tryacylglycerols typically provide a storage form of carbon to convert in energy that enables microalgae to endure adverse environmental conditions [47]. The diatoms Phaeodactylum tricornutum and Isochrysis galbana growing in different irradiance (50, 300, $600 \mu \mathrm{mol}$ photon $\mathrm{m}^{-2} \mathrm{~s}^{-1}$ ) increase the content of tryacylglycerols when grows in irradiances between 300 and 600 $\mu \mathrm{mol}$ photon $\mathrm{m}^{-2} \mathrm{~s}^{-1}$ [48]. However, in the same species diatom $P$. tricornutum when grows with nitrogen starvation, the highest tryacylglycerols was found in irradiances of $60 \mu \mathrm{mol}$ photon $\mathrm{m}^{-2} \mathrm{~s}^{-1}$ [49]. In this study, $A$. carterae had the highest lipid content in the lowest irradiance used $\left(50 \mu \mathrm{mol}\right.$ photon $\left.\mathrm{m}^{-2} \mathrm{~s}^{-1}\right)$. Maltsev et al. [20], describes that the optimal light intensity for the highest lipid content and productivity in not the same for different taxa of microalgae.

Other environmental parameters can influence the growth and proximate composition of different microalgae strains, e.g., Porphyridium cruentum maintained with low irradiance $\left(50 \mu \mathrm{mol}\right.$ photon $\left.\mathrm{m}^{-2} \mathrm{~s}^{-1}\right)$ and ammonium as nitrogen source, increase the lipid content [50]. However, Metsoviti et al. [51] mentioned that it is difficult to generalize the specific influence of the environmental factors on growth and biochemical composition in microalgae species due to differences in their metabolism. The results obtained in this work show that the lowest irradiances used on the cultures of $A$. carterae induce a low growth rate, increasing TDW, ODW, and lipid content by cell.

Proteins content for $A$. carterae in this work increases proportionally to irradiance level rises. This trend previously described was also observed in Scenedesmus obliquus [22]. Protein synthesis can be stimulated by factors like the nitrogen source, temperature, and light [51]. The protein content of $A$. carterae obtained in this study under the five irradiances $\left(62\right.$ to $\left.87 \mathrm{pg} \mathrm{cell}^{-1}\right)$, was similar to the values measured to the same specie but obtained from Woods Hole (Amphi 1) (100 to $220 \mathrm{pg} \mathrm{cell}^{-1}$ ) when was maintained with " $\mathrm{f} / 2$ " media, $20^{\circ} \mathrm{C}$ and $50 \mu$ mol photon $\mathrm{m}^{-2} \mathrm{~s}^{-1}$ [35]. Carbohydrate content obtained in this work had slight variation by the effect of the five irradiances used. The carbohydrate contents of $A$. carterae under the five irradiances (22 to $30 \mathrm{pg} \mathrm{cell}^{-1}$ ) were lower than the values obtained to other studies (40 to $90 \mathrm{pg} \mathrm{cell}^{-1}$ ), with the same specie but obtained from Woods Hole (Amphi 1) and culture

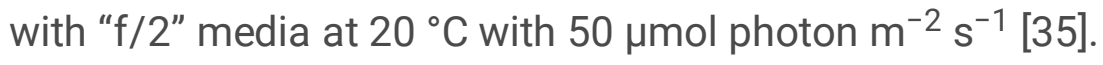

Chlorophyll a content had an inverse trend concerning the irradiance level used to $A$. carterae cultures in this work; this pattern is typical in all photosynthetic organisms [18]. One general response of microalgae to increase the photon flux densities is reducing cellular pigment content, regulating the light-harvesting antennas size, and modifying the cell size [52]. The chlorophyll a content obtained in this study (3.1 to 
$4.02 \mathrm{pg} \mathrm{cell}^{-1}$ ) was higher than the previously reported for $A$. carterae $[15,38,53]$. We considered that these differences are due to the characteristics of the strain used and distinct culture conditions.

Under high light irradiance, the excess energy absorbed can cause a destructive effect in the photosynthetic apparatus; carotenoids and their antioxidant capacity protect the photosystem from damage [54]. The carotenoid content was not modified by the effect of the irradiance in this work; thus, the light irradiance used is not too high to cause photodamage in the photosynthetic apparatus of $A$. carterae. The carotenoid content measured in this work ( 1.5 to $\left.1.84 \mathrm{pg} \mathrm{cell}^{-1}\right)$ was similar to the values mentioned to Amphidinium carterae by other authors (2 to $\left.5 \mathrm{pg} \mathrm{cell}^{-1}\right)[15,53]$.

For several microalgae groups, Fv/Fm values were described with mean values of 0.65 and indicate that the cells are without stress, when decreasing the values of Fv/Fm indicate stress [55]. The Fv/Fm ratio obtained on this work ( 0.21 to 0.38$)$ were similar to the values previously mentioned to $A$. carterae $(0.30$ to 0.40) [37]; however, the Fv/Fm values were lower than the obtained by Li et al. [38] (0.30 to 0.70) and by Molina-Miras et al. [15] (0.62). The lower Fv/Fm values obtained in the irradiance of $50 \mu \mathrm{mol}$ photon $\mathrm{m}^{-2} \mathrm{~s}^{-1}$ indicates that $A$. carterae is under stress condition with low photosynthetic efficiency. Moreover, the high $\mathrm{Fv} / \mathrm{Fm}$ ratio obtained in the different light irradiances used shows that photoinhibition is not produced and explains the photoacclimation of $A$. carterae to high irradiances. The irradiance of saturation $\left(I_{k}\right)$ observed in this work indicates that $A$. carterae can tolerate high irradiances.

\section{Conclusion}

In conclusion, the results obtained in this study indicate that the strain of $A$. carterae used in this work can grow in high irradiances ( 100 to $250 \mu \mathrm{mol}$ photon $\mathrm{m}^{-2} \mathrm{~s}^{-1}$ ). When the cultures of $A$. carterae were maintained under stress conditions with low irradiance $\left(50 \mu \mathrm{mol}\right.$ photon $\left.\mathrm{m}^{-2} \mathrm{~s}^{-1}\right)$, they produced low growth rates and photosynthetic activity; however, the lipid and carbohydrate contents increase and those can be used in the production of biodiesel or ethanol.

\section{Declarations}

\section{Acknowledgments}

We thank Fátima Y. Castro Ochoa and Ceres A. Molina Cárdenas for figure edition.

\section{Funding}

This work has been founded by Consejo Nacional de Ciencia y Tecnología (CONACyT) (Grant project: SEP - CONACyT 130074), and CICESE (gran project: 623108).

\section{Author contributions}


A. Mendoza-Flores: design and implementation of the experiments and manuscript preparation. M.P. Sánchez-Saavedra: design and supervision of experiments, data processing, contribution to manuscript preparation, and financial support. C.E. Galindo-Sánchez: contribution to manuscript preparation, and financial support.

\section{Declaration of competing interest}

The authors declare that they have no conflict of interest.

\section{Data availability}

The datasets generated during and/or analyzed during the current study are available from the corresponding author on reasonable request.

\section{References}

1. Venkata-Subhash G, Rajvanshi M, Kumar GRK, Shankar Sagaram U, Prasad V, Govindachary S, Dasgupta S (2022) Challenges in microalgal biofuel production: A perpective on techno economic feasibility under biorefinery stratagem. Bioresour Technol 343:126155.

https://doi.org/10.1016/j.biortech.2021.126155

2. Kowthaman CN, Senthil Kumar P, Mozhi Selvan VA, Ganesh D (2022) A comprehensive insigth from microalgae production process to characterization of biofuel for sustainable energy. Fuel 310:122320. https://doi.org/10.1016/j.fuel.2021.122320

3. Novoveská L, Ross ME, Stanley MS, Pradelles R, Wasiolek V, Sassi J-F (2019) Microalgal carotenoids: A review of production, current markets, regulations, and future direction. Mar Drugs 17:640. https://doi.org/10.3390/md17110640

4. Shi T-Q, Wang L-R, Zhang Z-X, Sun X-M, Huang H (2020) Stress as first-line tools for enhancing lipid and carotenoid production in microalgae. Front Bioeng Biotechnol 8:610. https://doi.org/10.3389/fbioe.2020.00610

5. Gallardo-Rodríguez J, Sánchez-Mirón A, García-Camacho F, López-Rosales F, Chisti Y, Molina-Grima E (2012) Bioactives from microalgal dinoflagellates. Biotechnol Adv 30:1673-1684. https://doi.org/10.1016/j.biotechadv.2012.07.005

6. Assunção J, Guedes CA, Malcata XF (2017) Biotechnological and pharmacological applications of biotoxins and other bioactive molecules from dinoflagellates. Mar Drugs 15:393. https://doi.org/10.3390/md15120393

7. Ishikawa C, Jomori T, Tanaka J, Senba M, Mori N (2016) Peridinin, a carotenoid, inhibits proliferation and survival of HTLV-1-infected T-cell lines. Int J Oncol 49:1713-1721. https://doi.org/10.3892/ijo.2016.3648

8. Simionato D, Basso S, Giacometti GM, Morosinotto T (2013) Optimization of light use efficiency for biofuel production in algae. Biophys Chem 182:71-78. https://doi.org/10.1016/j.bpc.2013.06.017 
9. Adarme-Vega TJ, Thomas-Hall SR, Schenk PM (2014) Towards sustainable sources for omega-3 fatty acids production. Curr Opin Biotechnol 26:14-18.

https://doi.org/10.1016/j.copbio.2013.08.003

10. Jørgensen MF, Murray S, Daugbjerg N (2004) Amphidinium revisited. I. Redefinition of Amphidinium (Dinophyceae) based on cladistic and molecular phylogenetic analyses. J Phycol 40:351-365. https://doi.org/10.1111/j.1529-8817.2004.03131.x

11. Schiller J (1933) Dinoflagellate (Peridineae) kryptogamen-flora. Akad Verl Leipzig 10:276-322

12. Morsy N, Houdai T, Matsuoka S, Matsumori N, Adachi S, Oishi T, Murata M, Iwashita T, Fujita T (2006) Structures of new amphidinols with truncated polyhydroxyl chain and their membranepermeabilizing activities. Bioorganic Med Chem 14:6548-6554.

https://doi.org/10.1016/j.bmc.2006.06.012

13. Wakamiya Y, Ebine M, Matsumori N, Oishi T (2020) Total synthesis of amphidinol 3: A general strategy for synthesizing amphidinol snalogues and structure-activity relationship study. J Am Chem Soc 142:3472-3478. https://doi.org/10.1021/jacs.9b11789

14. Wellkamp M, García-Camacho F, Durán-Riveroll LM, Tebben J, Tillmann U, Krock B (2020) LC-MS/MS method development for the discovery and identification of amphidinols produced by Amphidinium. Mar Drugs 18:497. https://doi.org/10.3390/md18100497

15. Molina-Miras A, López-Rosales L, Sánchez-Mirón A, Cerón-García MC, Seoane-Parra S, GarcíaCamacho F, Molina-Grima E (2018a) Long-term culture of the marine dinoflagellate microalga Amphidinium carterae in an indoor LED-lighted raceway photobioreactor: Production of carotenoids and fatty acids. Bioresour Technol 265:257-267. https://doi.org/10.1016/j.biortech.2018.05.104

16. Molina-Miras A, Morales-Amador A, de Vera CR, López-Rosales L, Sánchez-Mirón A, Souto ML, Fernández JJ, Norte M, García-Camacho F, Molina-Grima E (2018b) A pilot-scale bioprocess to produce amphidinols from the marine microalga Amphidinium carterae: Isolation of a novel analogue. Algal Res 31:87-98. https://doi.org/10.1016/j.algal.2018.01.010

17. López-Rodríguez M, Cerón-García MC, López-Rosales L, González-López CV, Molina-Miras A, RamírezGonzález A, Sánchez-Mirón A, García-Camacho F, Molina-Grima E (2019) Assessment of multi-step processes for an integral use of the biomass of the marine microalga Amphidinium carterae. Bioresour Technol 282:370-377. https://doi.org/10.1016/j.biortech.2019.03.041

18. Dubinsky Z, Matsukawa R, Karube I (1995) Photobiological aspects of algal mass culture. J Mar Biotechnol 2:61-65

19. Muller-Feuga A, Moaly J, Kaas R (2007) The microalgae of aquaculture. In: Støttrup JG, McEvoy LA (eds) Live feeds in marine aquaculture. Blackwell Science, Oxford, pp 207-252

20. Maltsev Y, Maltseva K, Kulikovskiy M, Maltseva S (2021) Influence of light conditions on microalgae growth and content of lipids, carotenoids, and fatty acid composition. Biology 10:1060. https://doi.org/10.3390/biology 10101060

21. Grobbelaar JU (2010) Microalgal biomass production: Challenges and realities. Photosynth Res 106:135-144. https://doi.org/10.1007/s11120-010-9573-5 
22. Gris B, Morosinotto T, Giacometti GM, Bertucco A, Sforza E (2014) Cultivation of Scenedesmus obliquus in photobioreactors: Effects of light intensities and light-dark cycles on growth, productivity, and biochemical composition. Appl Biochem Biotechnol 172:2377-2389. https://doi.org/10.1007/s12010-013-0679-z

23. Guillard RRL, Ryther JH (1962) Studies om marine planktonic diatoms I. Cyclotella nana Hustedt and Detonula confervacea (Cleve). Gran Can J Microbiol 8:229-239. https://doi.org/10.1139/m62-029

24. Guillard RRL (1973) Division rates. In: Stein JR (ed) Handbook of phycological methods. Culture methods and growth measurements. Cambridge University Press, Crambridge, pp 96-97

25. Jeffrey SW, Humphrey GF (1975) New spectrophotometric equations for determining chlorophylls a, b, 11 and $\mathrm{c} 2$ in higher plants, algae and natural phytoplankton. Biochem und Physiol der Pflanz 167:191-194

26. Eilers PHC, Peeters JCH (1988) A model for the relationship between light intensity and the rate of photosynthesis in phytoplankton. Ecol Model 42:199-215. https://doi.org/10.1016/03043800(88)90057-9

27. Sorokin C (1973) Dry weight, packed cell volume and optical density. In: Stein JR (ed) Handbook of phycological methods and growth measured, 3rd edn. Cambridge University Press, New York, pp $321-343$

28. Safi C, Ursu AV, Laroche C, Zebib B, Merah O, Pontalier PY, Vaca-García C (2014) Aqueous extraction of proteins from microalgae: effect of different cell disruption mehtods. Algar Res 3:61-65

29. Lowry OH, Rosebrough HJ, Faar AL, Randall RJ (1951) Protein Measurement byt the Folin Reagent. J Biol Chem 193:265-275

30. Whyte JNC (1987) Biochemical composition and energy content of six species of phytoplankton used in mariculture of bivalves. Aquaculture 60:231-241

31. Dubois M, Gilles KA, Hamilton JK, Rebers PA, Smith F (1956) Colorimetric method for determination of sugars and related substances. Anal Chem 28:350-356

32. Bligh EG, Dyer WJ (1959) Canadian Journal of Biochemistry and Physiology. Can J Biochem Physiol 37:911-917

33. Pande SV, Khan RP, Venkitasubramanian TA (1963) Microdetermination of lipids and serum total fatty acids. Anal Biochem 6:415-423. https://doi.org/10.1016/0003-2697(63)90094-0

34. Samuelsson G, Richardson K (1982) Photoinhibition at low quantum flux densities in a marine dinoflagellate (Amphidinium carterae). Mar Biol 70:21-26. https://doi.org/10.1007/BF00397292

35. Thomas PH, Carr NG (1985) The invariance of macromolecular composition with altered light limited growth rate of Amphidinium carteri (dinophyceae). Arch Microbiol 142:81-86

36. Dixon GK, Syrett PJ (1988) The growth of dinoflagellates in laboratory cultures. New Phytol 109:297-302. https://doi.org/10.1111/j.1469-8137.1988.tb04198.x

37. Aquino-Cruz A, Okolodkov YB (2016) Impact of increasing water temperature on growth, photosynthetic efficiency, nutrient consumption, and potential toxicity of Amphidinium cf. carterae 
and Coolia monotis (Dinoflagellata). Rev Biol Mar Oceanogr 51:565-580.

https://doi.org/10.4067/S0718-19572016000300008

38. Li M, Shi X, Guo C, Lin S (2016) Phosphorus deficiency inhibits cell division but not growth in the dinoflagellate Amphidinium carterae. Front Microbiol 7:1-11.

https://doi.org/10.3389/fmicb.2016.00826

39. Valenzuela-Espinoza E, Millán-Núñez R, Santamaría-del Ángel E, Trees CC (2011) Macronutrient uptake and carotenoid/chlorophyll a ratio in the dinoflagellate Amphidinium carteri Hulburt, cultured under different nutrient and light conditions. Hidrobiológica 21:34-48

40. Leynse AK, Parsons ML, Thomas SE (2017) Differences in the photoacclimation and photoprotection exhibited by two species of the ciguatera causing dinoflagellate genus. Gambierdiscus Harmful Algae 70:90-97. https://doi.org/10.1016/j.hal.2017.10.008

41. Wahidin S, Idris A, Shaleh SRM (2013) The influence of light intensity and photoperiod on the growth and lipid content of microalgae Nannochloropsis sp. Bioresour Technol 129:7-11.

https://doi.org/10.1016/j.biortech.2012.11.032

42. Hu Q, Sommerfeld M, Jarvis E, Ghirardi M, Posewitz M, Seibert M, Darzond A (2008) Microalgal triacylglycerols as feedstocks for biofuel production: perspectives and advances. Plant J 54:621639. https://doi.org/10.1111/j.1365-313X.2008.03492.x

43. Makri A, Bellou S, Birkou M, Papatrehas K, Dolapsakis NP, Bokas D, Papanikolaou S, Aggelis G (2011) Lipid synthesized by micro-algae grown in laboratory- and industrial-scale bioreactors. Eng Life Sci 11:52-58. https://doi.org/10.1002/elsc.201000086

44. Weldy C, Huesemann M (2007) Lipid production by Dunaliella salina in batch culture: effects of nitrogen limitation and light intensity.J Undergrad Res115-122

45. MacDougall KM, McNochol J, McGinn PJ, O'Leary SJB, Melanson JE (2011) Triacylglycerol profiling of microalgae strains for biofuel feedstock by liquid chromatography-high-resolution mass spectrometry. Anal Bioanal Chem 401:2609-2616. https://doi.org/10.1007/s00216-011-5376-6

46. Williams PJB, Laurens LML (2010) Microalgae as biodiesel and biomass feedstock: Review and analysis of the biochemistry, energetics and aconomics. Energy Environ Sci 3:554-590. https//doi.org/10.1039/b924978h

47. Sharma KK, Schuhmann H, Schenk PM (2012) High lipid induction in microalgae for biodiesel production. Energies 5:1532-1553. https://doi.org/10.3390/en5051532

48. Nogueira DPK, Silva AF, Araújo OFQ, Chaloub RM (2015) Impact of temperature and light intensity on triacylglycerol accumulation in marine microalgae. Biomass Bioenergy 72:280-287. http://dx.doi.org/10.1016/j.biombioe.2014.10.017

49. Remmers IM, Martens DE, Wijffels RH, Lamers PP (2017) Dynamics of tryacylglycerol and EPA production in Phaedacty/um tricornutum under nitrogen starvation at different light intensities. PLoS ONE 12:e0175630. https://doi.org/10.1371/journal.pone.0175630

50. Sánchez-Saavedra MP, Castro-Ochoa FY, Nava-Ruiz VM, Ruiz-Güereca DA, Villagómez-Aranda AL, Siqueiros-Vargas F, Molina-Cárdenas CA (2018) Effects of nitrogen source and irradiance on 
Porphyridium cruentum. J Appl Phycol 30:783-792. https://doi.org/10.1007/s10811-017-1284-2

51. Metsoviti MN, Papapolymerou G, Karapanagiotidis IT, Katsoulas N (2019) Comparison of growth rate and nutrient content of five microalgae species cultivated in greenhouses. Plants 8:1-13. https://doi.org/10.3390/plants8080279

52. Richardson K, Beardall J, Raven JA (1983) Adaptation of unicellular algae to irradiance: an analysis of strategies. New Phytol 93:157-191. https://doi.org/10.1111/j.1469-8137.1983.tb03422.x

53. Ruivo M, Amorim A, Cartaxana P (2011) Effects of growth phase and irradiance on phytoplankton pigment ratios: Implications for chemotaxonomy in coastal waters. J Plankton Res 33:1012-1022. https://doi.org/10.1093/plankt/fbr019

54. Xiao FG, Shen L, Ji HF (2011) On photoprotective mechanisms of carotenoids in light harvesting complex. Biochem Biophys Res Commun 414:1-4. https://doi.org/10.1016/j.bbrc.2011.09.049

55. Tan L, Xu W, He X, Wang J (2019) The feasibility of Fv/Fm on judging nutrient limitation of marine algae through indoor simulation and in situ experiment. Estuar Coast Shelf Sci 229:106411. https://doi.org/10.1016/j.ecss.2019.106411

\section{Tables}

Table 1 Mean values $(n=3)$ and standard deviation of photosynthetic parameters of Amphidinium carterae cultures maintained under five irradiances. Photosynthetic efficiency (a), irradiance of saturation $\left(I_{k}\right)$ and maximum relative electron transport rate $(\mathrm{rETRm})$.

\begin{tabular}{|c|c|c|c|}
\hline $\begin{array}{l}\text { Irradiance } \\
\left.\text { ( } \mu \text { mol photons } \mathrm{m}^{-2} \mathrm{~s}^{-1}\right)\end{array}$ & $\begin{array}{l}\text { a } \\
\left(\mathrm{O}_{2} \text { photon }^{-1}\right)\end{array}$ & $\begin{array}{l}\text { rETRm } \\
\text { ( } \mu \mathrm{mol} \text { electrons } \mathrm{m}^{-2} \mathrm{~s}^{-1} \text { ) }\end{array}$ & $\begin{array}{l}I_{k} \\
\left(\mu \mathrm{mol} \text { photons } \mathrm{m}^{-2} \mathrm{~s}^{-1}\right)\end{array}$ \\
\hline 50 & $0.0035 \pm 0.0006 c$ & $6.15 \pm 3.88 c$ & $2032.68 \pm 778.07 a b$ \\
\hline 100 & $0.0072 \pm 0.0014 b$ & $11.10 \pm 5.58 b$ & $1906.70 \pm 108.48 b$ \\
\hline 150 & $0.0076 \pm 0.0017 b$ & $9.20 \pm 0.23 b$ & $1918.63 \pm 633.85 b$ \\
\hline 200 & $0.0140 \pm 0.0051 a$ & $21.06 \pm 7.04 a$ & $2249.70 \pm 460.50 a$ \\
\hline 250 & $0.0086 \pm 0.0015 b$ & $12.70 \pm 3.12 b$ & $1858.86 \pm 400.80 \mathrm{~b}$ \\
\hline
\end{tabular}

Values with different letters indicate significant differences by irradiance (One-way ANOVA and a Tukey a posteriori test, $a=0.05: a>b>c$.

\section{Figures}




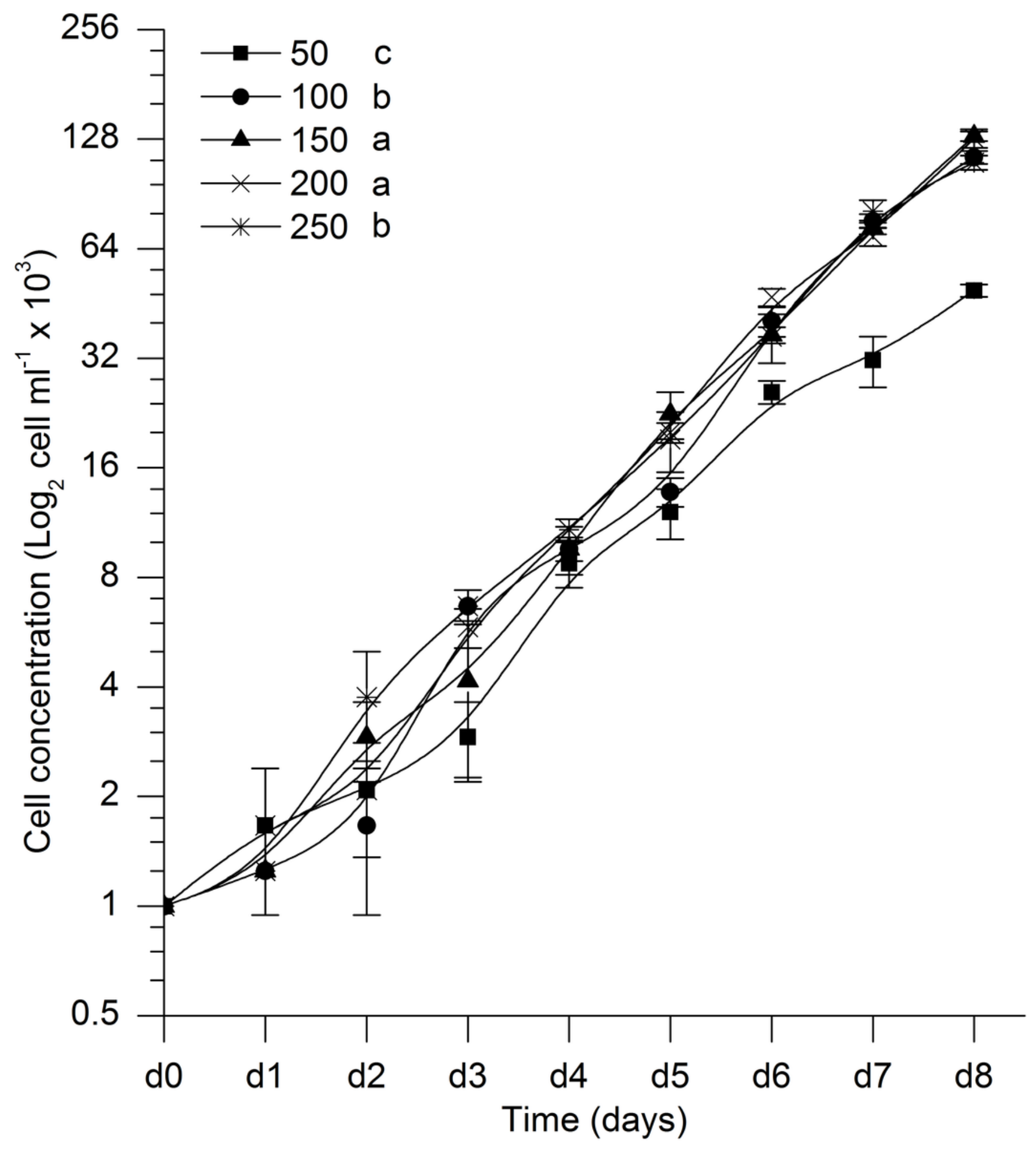

Figure 1

Mean values $(n=3)$ and standard deviations of cell concentration during the growth of Amphidinium carterae cultured under five irradiancies $\left(50,100,150,200\right.$, and $250 \mu \mathrm{mol}$ photons $\left.\mathrm{m}^{-2} \mathrm{~s}^{-1}\right)$. Different letters indicate significant differences by irradiance (covariance analysis ANCOVA and a Tukey $a$ posteriori test, $a=0.05: a>b>c)$. 


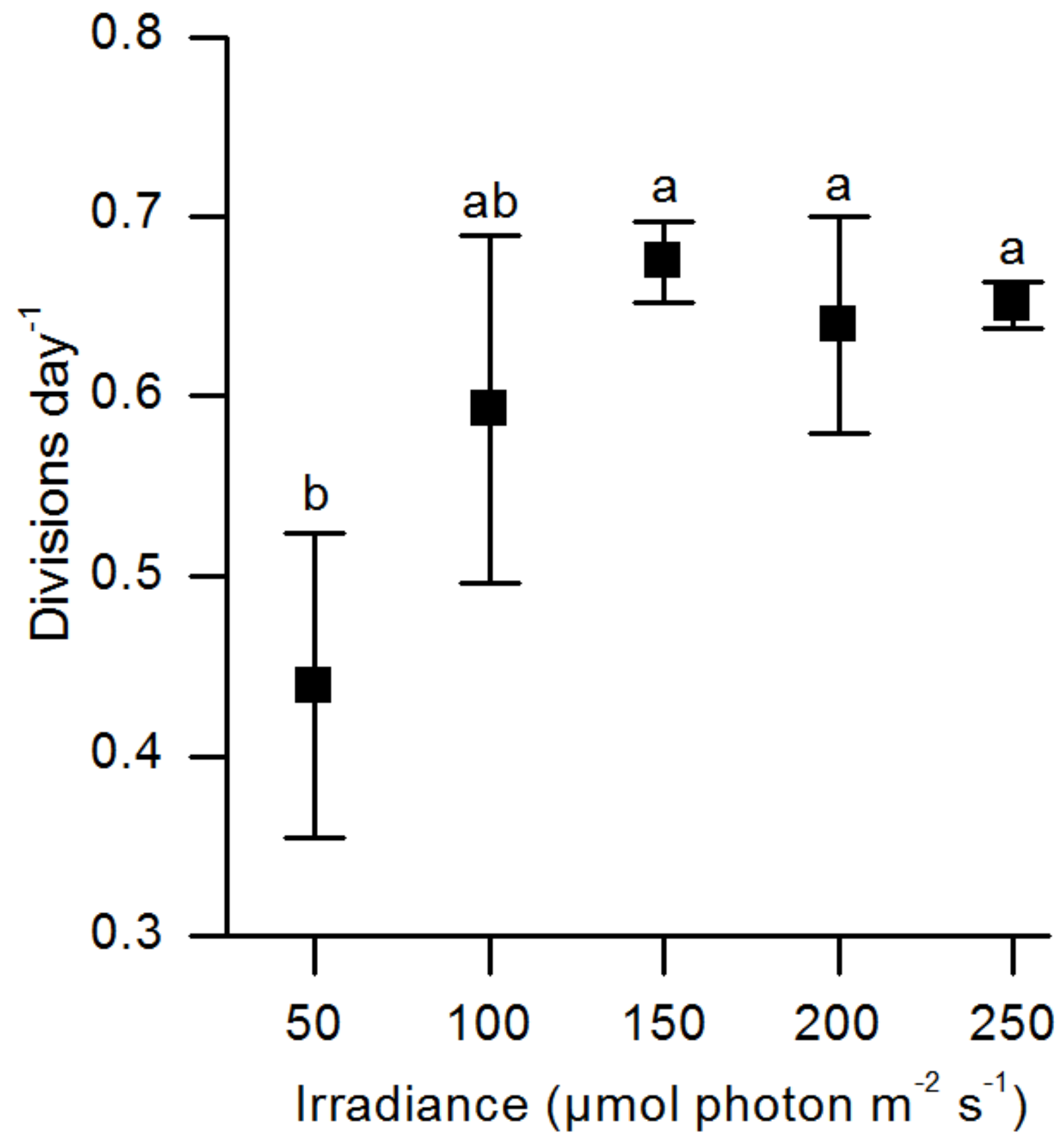

Figure 2

Mean values and standard deviations ( $n=3$ ) of growth rate (divisions day ${ }^{-1}$ ) of Amphidinium carterae cultures maintained under five irradiancies. Different letters indicate significant differences by irradiance (one-way ANOVA and a Tukey a posteriori test, $a=0.05$ : $a>b$ ). 


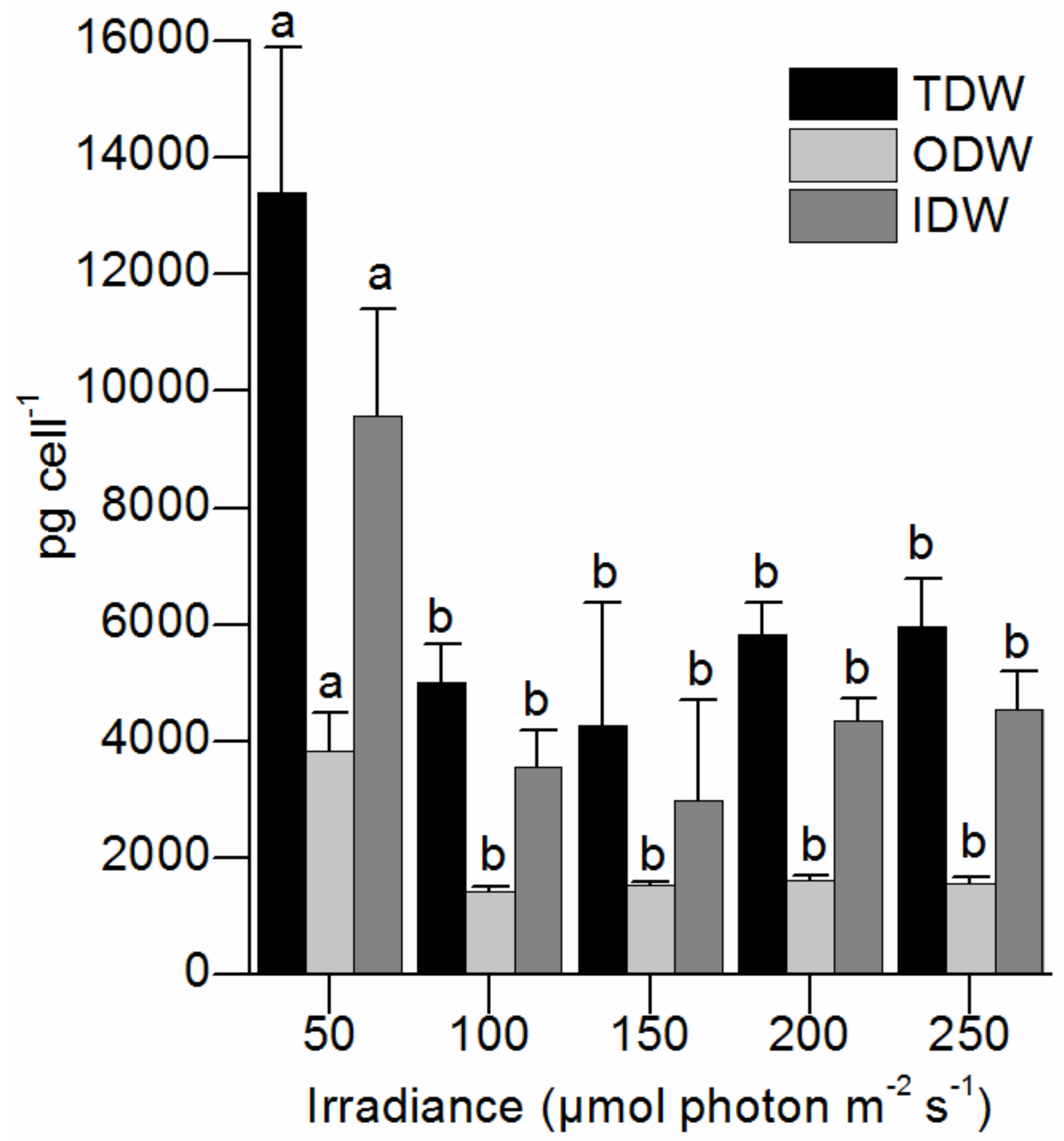

Figure 3

Mean values and standard deviations ( $n=3)$ of total dry weight (TDW), organic dry weight (ODW) and inorganic dry weight (IDW) (pg cell ${ }^{-1}$ ) of Amphidinium carterae cultures maintained under five irradiancies. Different letters indicate significant differences by irradiance (one-way ANOVA and a Tukey $a$ posteriori test, $a=0.05$ : $a>b)$. 


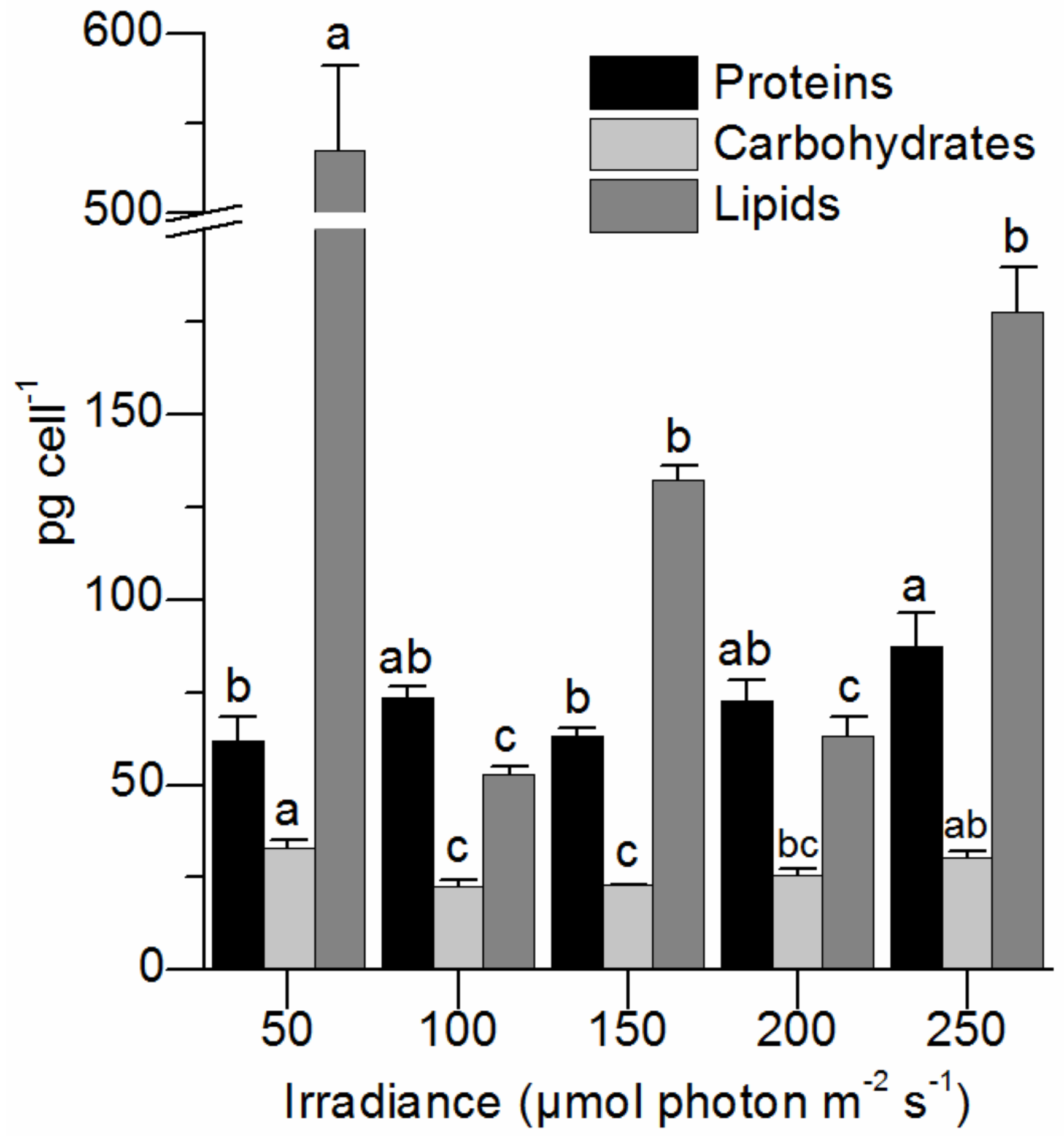

Figure 4

Mean values and standard deviations $(n=3)$ of proximate composition of proteins, carbohydrates and lipids ( $\mathrm{pg}$ cell $^{-1}$ ) of Amphidinium carterae cultures maintained under five irradiancies. Different letters indicate significant differences by irradiance (one-way ANOVA and a Tukey a posteriori test, a $=0.05$ : $a>b>c)$. 


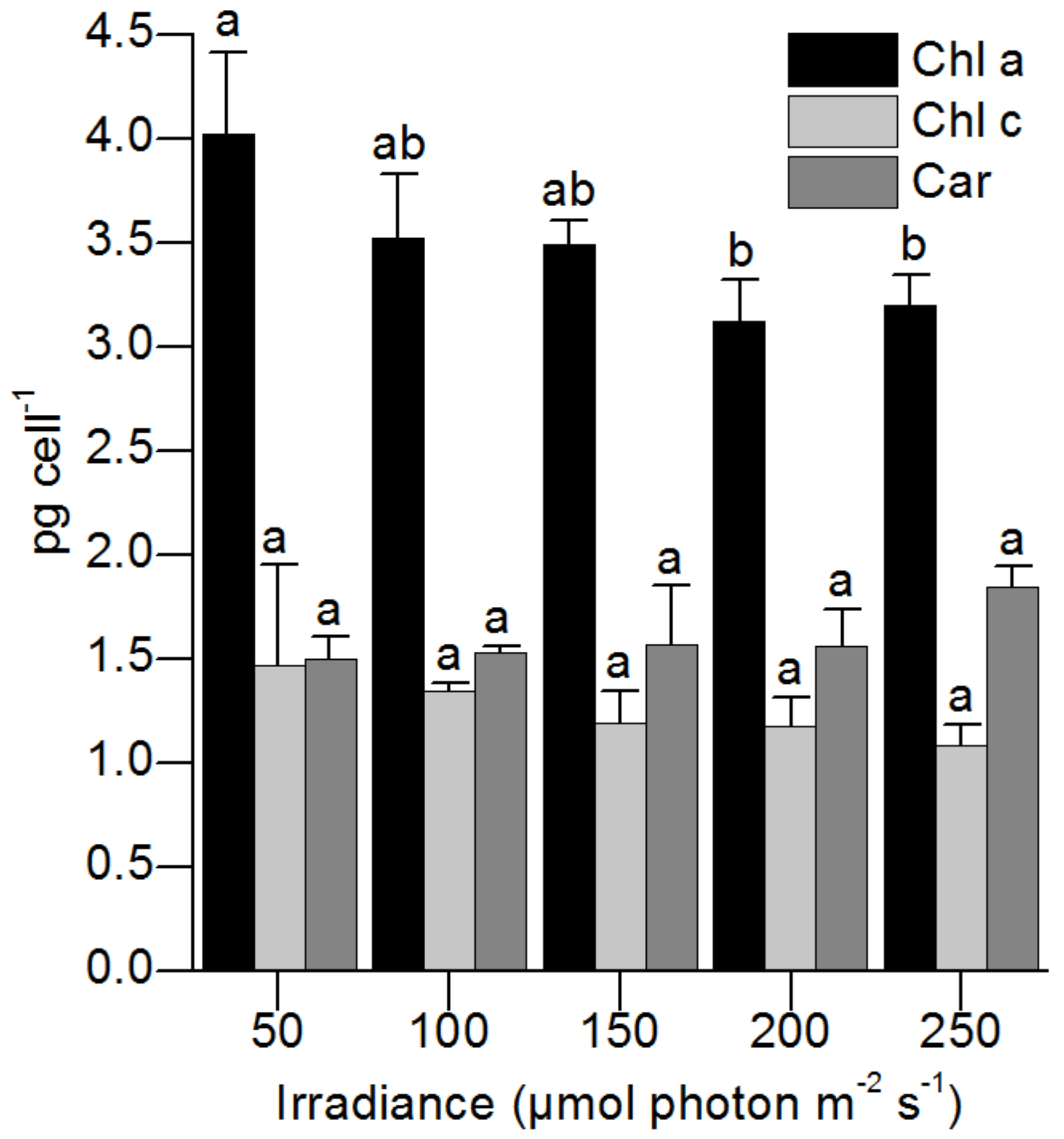

Figure 5

Mean values and standard deviations $(n=3)$ of pigment content of chlorophyll a (chl a), chlorophyll c (chl

c) and carotenoid content ( $\mathrm{pg}$ cell $^{-1}$ ) of Amphidinium carterae cultures maintained under five irradiancies. Different letters indicate significant differences by irradiance (one-way ANOVA and a Tukey a posteriori test, $a=0.05: a>b)$. 


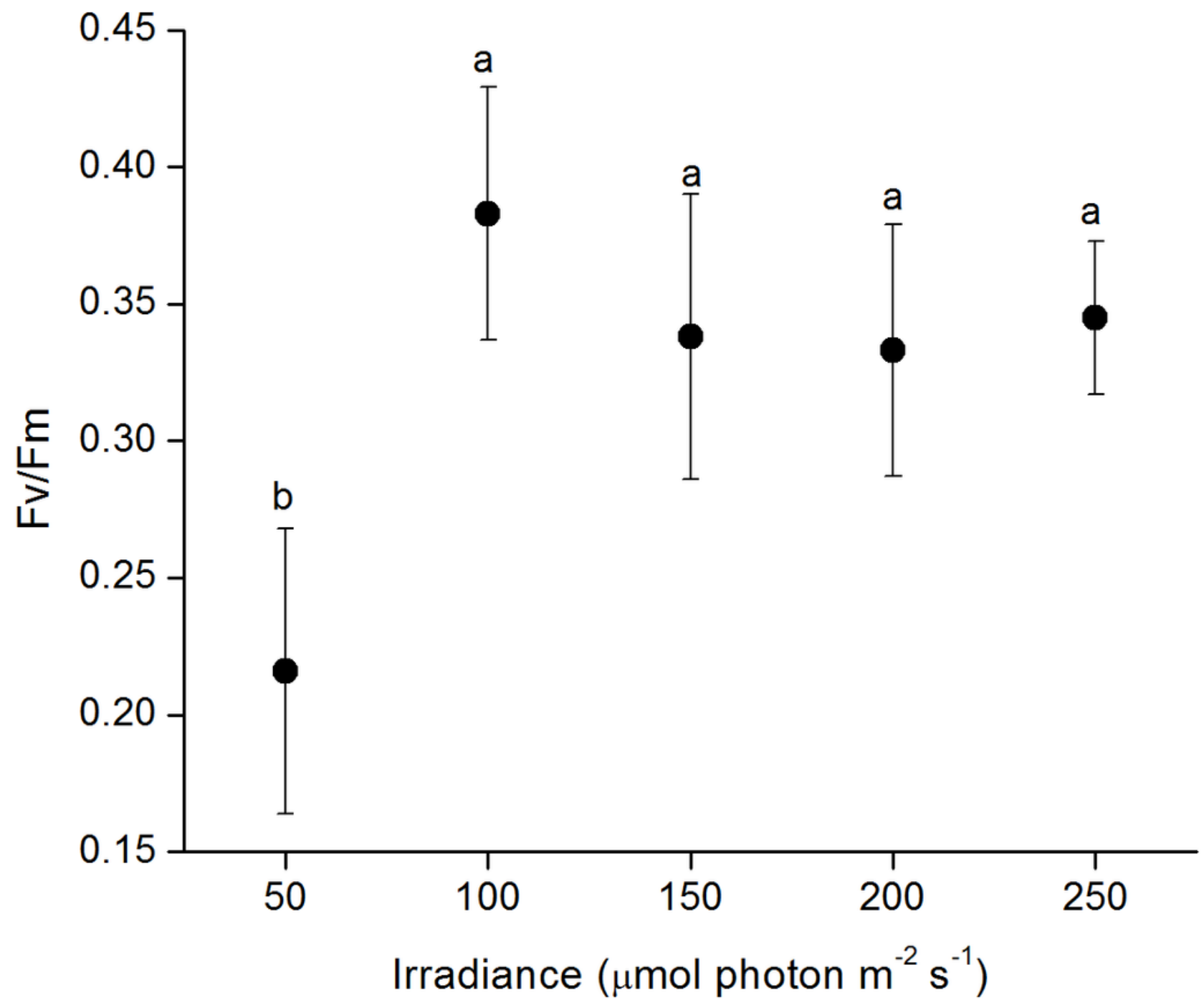

Figure 6

Mean values and standard deviations ( $n=3)$ of maximum quantum yield photosystem II (Fv/Fm) of Amphidinium carterae cultures maintained under five irradiancies. Different letters indicate significant differences by irradiance (one-way ANOVA and a Tukey a posteriori test, $a=0.05$ : $a>b$ ). 


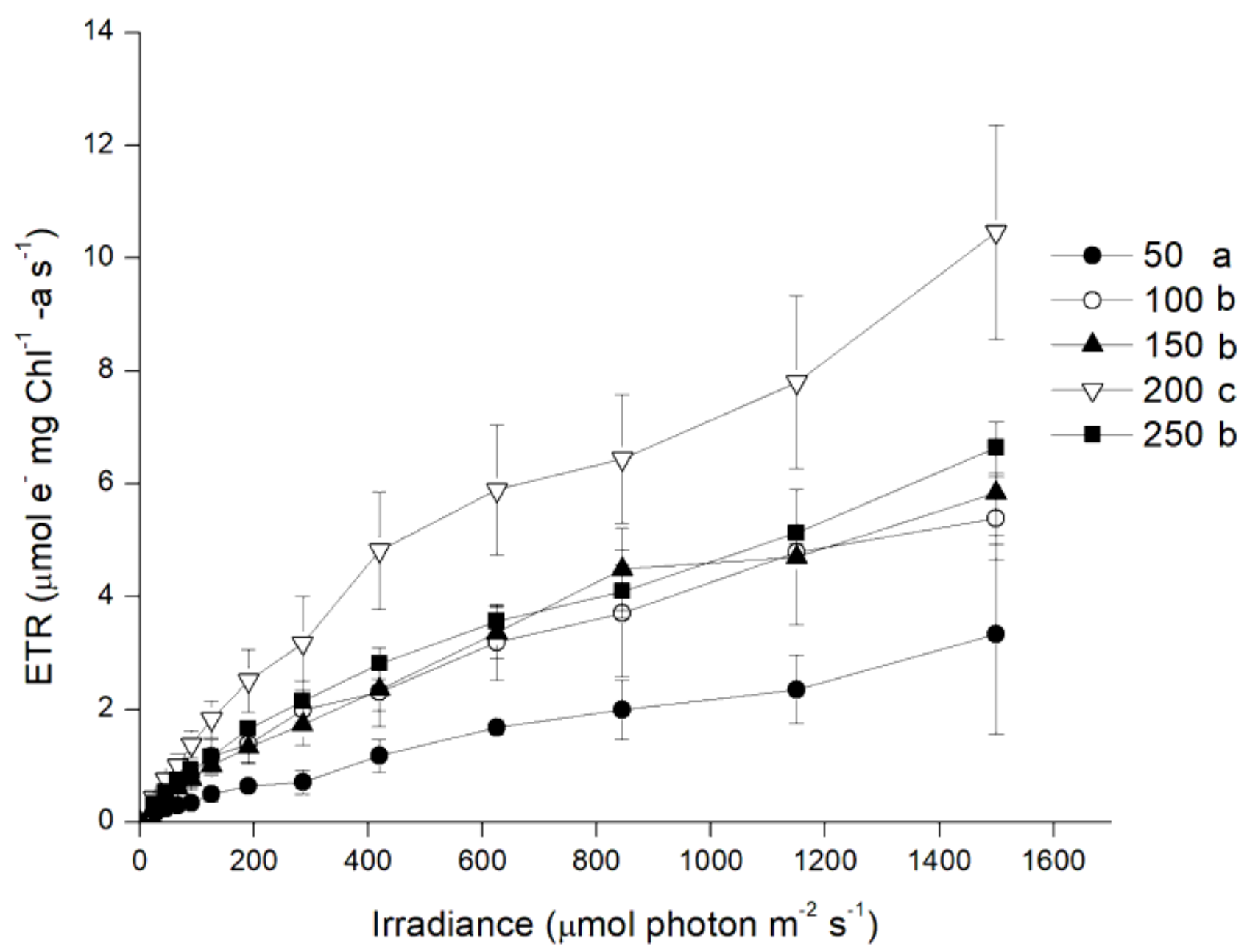

Figure 7

Mean values $(n=3)$ and standard deviations of photosynthetic curves measured as relative electron transport (ETR) of Amphidinium carterae cultured under five irradiancies (50, 100, 150, 200, and $250 \mu \mathrm{mol}$ photons $\mathrm{m}^{-2} \mathrm{~s}^{-1}$ ). Different letters indicate significant differences by irradiance (covariance analysis ANCOVA and a Tukey a posteriori test, $a=0.05: a>b>c$ ). 